\title{
Professional Development Needs Of English Language Teachers In Malaysia
}

Koroush Khandehroo, Islamic Azad University, Neyshabur Branch, Iran

Jayakaran Mukundan, Universiti Putra Malaysia, Malaysia

Zhinoos Kamal Alavi, Multimedia University, Malaysia

\begin{abstract}
This study surveyed the professional development (PD) needs of school English language teachers at Melaka State in Malaysia. With close cooperation with the Department of Language at the Ministry of Education, the whole population of English language teachers had been studied on their types of professional development needs in instructional skills. The data showed that 99\% of the English language teachers perceived that they needed professional development at some level while only about $1 \%$ stated no need to any types of PD activities. Nearly 50\% indicated their need for PD to be very high or high. Maintaining language skills, assessing students, and using cooperative learning were respectively the first, second and third instructional skills for which teachers indicated very high or high levels of need for PD. The quantitative data also shed light on how PD needs were related to the demographic factors of the participants. The results of this study would give insightful feedback to the administrators of the Language Department in Malaysia to better design PD activities with more developmental outcomes.
\end{abstract}

Keywords: Professional Development; Need; Demographic Factors

\section{INTRODUCTION}

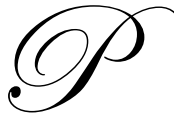

rofessional development opportunities for teachers have rarely been on the basis of their real needs for learning the instructional skills. Very few people in charge of administrative affairs might gain insights taken from teachers' professional needs. Having student teachers required to take part in diverse professional development activities irrelevant to what they need would lead them to view the opportunities merely as financial promoting courses rather than mediums for in-service teaching empowerment.

Reviewing the related literature in the area of teacher Professional Development (PD), a mammoth body of research has been elaborated on the effectiveness of PD activities, or opportunities (Desimone, 2009; Gersten \& Santoro, 2010; Garet, Porter, Desimone, Birman, \& Yoon, 2001; Lucks-Horsley \& Matsumoto, 1999). Research has also indicated that the teachers' Need for Professional Development (NPD) may vary with regards to certain demographic factors, such as experience levels, or school setting. Geary (1999) and Stroot, Langholz, Fowlkes, Paxton, Stedfnan, Steffes and Valtman (1999) provide support for the idea that novice teachers need different types of PD activities than other teachers. Stroot, et al. also found that the quantity of PD activities and support was also important for new teachers in that they asked for even more activities than they were already being given. In its 1998 study, the National Center for Education Statistics also supports this notion, as it took great care to report information based on teacher and school population data. For example, the data were broken down into categories by years of teacher experience, the level of the school (elementary, middle secondary or combined), the size of the student population in the schools, the school setting, the gender of the teacher, and the race of the teacher. The premise behind this is that what is useful to one teacher in one educational setting may not be functional to another teacher in another educational setting.

However, very few descriptive research designs have showed what instructional skills teachers need PD for. Kohl (2005) elaborated on the K12 ESL and EFL teachers' NPD in North Carolina. With a survey questionnaire including thirteen items for instructional skills, majority of the participants showed their higher levels of needs at PD 
activities for the purpose of development in teaching students with special needs, collaborative learning, and using technology. In Kohl's study, the relationships between some of the teachers' demographic variables and their perceived levels of NPD were highlighted.

\section{RATIONALE}

In the developing structure of Malaysian educational system, planning PD activities and opportunities for English language teachers is an essential necessity when it is executed on the basis of the teachers' needs and preferences. Malaysian English language teachers have faced a lot of variations in policies for which they were required to change their teaching methods and practices in the classroom. These changes required them to be constantly developed professionally; otherwise, they got indulged in burnt out (Mukundan and Khandehroo, 2009). In their study on Malaysian English language teachers, Mukundan and Khandehroo found out that various factors have significant contributions to the emotional, mental, and professional aspects of the teachers' behaviors. One of the factors being scrutinized was workload. The English language teachers as the participants of the study showed they could hardly manage their time to self-develop professionally and they preferred to have a structured plan for their professional growth.

Due to the various systemic changes with educational aims and policies for the English language in Malaysia, a collection of studies have been designed to examine the effectiveness of PD activities on meeting the needs of English language teachers presupposed by the administrators. However, this study was conducted to find out the Malaysian English language teachers' perception of their NPD as well as to discover levels of their needs to instructional skills. In addition, tests were conducted to realize if there are relations between their demographic variables and NPD levels.

\section{METHODOLOGY}

The target population participated in the survey comprised all the English language teachers currently employed in Melaka State public schools. The population list was obtained from the State Ministry of Education. With reference to the report of the Education Department, the total number of English language teachers in Melaka State was 1098 including both male and female teachers teaching either at the primary or secondary levels in both rural and urban areas. Having distributed the questionnaires to this population, they were asked to send them back completed in a period of two weeks. About $74 \%$ returned the booklet on time; however, $19.5 \%$ made a 4 -week delay. About 5.5\% did not respond well or send back the booklets to the researcher. Consequently, 1035 English language teachers teaching at primary and secondary schools in Melaka remained as valid respondents.

Out of 1035 English language teachers as the participants, 190 were male and 845 were female. With regards to their ethnicity, 499 were Malay, 410 Chinese, 117 Indian, and only 9 from other races. Based on their educational levels, 458 had diplomas, 527 bachelors, 48 masters, and merely 2 PhDs. Regarding school teaching level, 682 were primary and 353 secondary school teachers. With reference to their age, 165 were between 20 to 30 , 275 between 31 to 40, and 595 more than 41 years old. Finally, the number of those with 5 or less and 6-15 years of teaching experience was 192 and 276 respectively, while the participants with 16 and more years of teaching experience were and 567.

Finding an instrument that fits the study requirements was so challenging, because very few studies have been conducted on the PD needs of English language teachers. The researcher could finally employ the modified version of Kohl's (2005) Survey of Professional Development Needs of Second Language Teachers (SPDNSLT) that was also used for studies in foreign language setting in North Carolina. The context in which the available questionnaire was to be employed was different because only English language teachers were aimed to be the target population in this study. Therefore, modifications after a pilot study made the survey instrument applicable for the participants. 


\section{RESULTS AND DISCUSSIONS}

The first objective of the study was to determine the levels of the English language teachers' NPD. In order to investigate this, the respondents were asked how they would rate their personal NPD specifically in the area of English language teaching.

Table 1

Frequency distribution for the levels of personal NPD

\begin{tabular}{|c|c|c|}
\hline NPD & Frequency & Percentage \\
\hline Very high & 84 & 8.1 \\
\hline High & 418 & 40.4 \\
\hline Moderate & 483 & 46.7 \\
\hline Low & 42 & 4.1 \\
\hline No & 8 & 0.8 \\
\hline Total & 1035 & 100 \\
\hline
\end{tabular}

With reference to Table 1, more than $95 \%$ of the population reported moderate to very high NPD in the field of their expertise. Out of this target proportion, more than 48\% reported high and very high levels of NPD. Only $4.1 \%$ stated low and merely $0.8 \%$ indicated no need. This shows that majority of the English language teachers in Melaka feel the necessity of offering in service PD activities. It might be due to lack of access to different types of events or activities set for their development in the educational system.

An additional intent of the study was to investigate the English language teachers' levels of NPD in instructional skills. Therefore, the second part of the survey collected data on the teacher's NPD level for the following instructional skills:

1. Maintaining language skills

2. Building awareness of target culture or multicultural education

3. Assessing students

4. Using cooperative learning

5. Improving classroom management skills

6. $\quad$ Planning lessons and units

7. Applying English language teaching national standards

8. Using technology

9. Teaching students with special needs

10. Practice of ELT methodologies

\section{LEVELS OF NPD FOR INSTRUCTIONAL SKILLS}

The participants' responses to each item ranged from 0 to 4, meaning no to very high levels of NPD for instructional skills. Referring to Table 2, 54.6\% of English language teachers show their NPD to maintaining language skills with high and very high degree while $38.6 \%$ reported the need at the moderate level. Only 5.3 and $1.4 \%$ stated low and not applicable respectively. In building awareness of target culture or multi-cultural education, $48.3 \%$ reported high and very high need and about the same percentage (45\%) affirmed the need at moderate level. Merely about 8\% reported low and not applicable for this skill. As to another instructional skill, assessing students, about 10\% of the population marked very high and around 7\% reported low level of NPD. About $51 \%$ reported high and very high NPD for the skill. Using cooperative learning was the fourth skill for which about 49\% mentioned their need as high and very high while the ones indicating moderate amounted to $45.5 \%$. Merely about 5\% marked low and only 1 participant indicated not applicable for this item. Improving classroom management was asked in the fifth item for which around $42.3 \%$ reported moderate while $48.5 \%$ indicated high and very high NPD. Less than $8 \%$ stated low need and $1.4 \%$ labeled the item as not-applicable. For the instructional skill of planning lessons and units, about 46\% implied high and very high. Around 45\% reported moderate, $7.7 \%$ indicated low and merely 1\% mentioned it as not applicable. In applying English language teaching national standards, around $47 \%$ showed their appeal for PD activities at high and very high levels. Very similar to the 
previous skill, nearly the same number of teachers (470) reported their NPD at a moderate level. Less than $8 \%$ stated low and not applicable for this skill. Using technology as another instructional skill was questioned in the eighth item for which about $46 \%$ reported high and very high; whereas nearly $47 \%$ reported a moderate level of need. Only about 6\% claimed to have low need at improving their technological skills in English Language teaching. For teaching students with special needs, $46.2 \%$ showed high and very high levels of NPD. Teachers reporting their need at a moderate level constituted 39\% of the target population. Merely 9\% claimed to have low need and about $6 \%$ labeled the item as not applicable. Finally, in favor of the NPD for improving ELT methodologies, majority of the teachers, meaning 39\%, stated moderate while about $43 \%$ showed their need at the skill as high and very high and simply about $7.4 \%$ indicated low and not applicable.

Table 2

Levels of need for instructional skills

\begin{tabular}{|c|c|c|c|c|c|c|c|c|c|c|c|}
\hline \multirow{2}{*}{$\begin{array}{c}\text { Instructional } \\
\text { Skills }\end{array}$} & \multicolumn{2}{|c|}{ Not Applicable } & \multicolumn{2}{|c|}{ Low } & \multicolumn{2}{c|}{ Moderate } & \multicolumn{2}{c|}{ High } & \multicolumn{2}{c|}{ Very High } & Total \\
\cline { 2 - 12 } & $\mathbf{F}$ & $\mathbf{P}$ & $\mathbf{F}$ & $\mathbf{P}$ & $\mathbf{F}$ & $\mathbf{P}$ & $\mathbf{F}$ & $\mathbf{P}$ & $\mathbf{F}$ & $\mathbf{P}$ & \\
\hline 1 & 15 & 1.4 & 55 & 5.3 & 400 & 38.6 & 441 & 42.6 & 124 & 12 & 1035 \\
\hline 2 & 11 & 1.1 & 59 & 5.7 & 466 & 45 & 427 & 41.3 & 72 & 7.0 & 1035 \\
\hline 3 & 6 & 0.6 & 68 & 6.6 & 434 & 41.9 & 431 & 41.6 & 96 & 9.3 & 1035 \\
\hline 4 & 1 & 0.1 & 54 & 5.2 & 471 & 45.5 & 427 & 41.3 & 82 & 7.9 & 1035 \\
\hline 5 & 14 & 1.4 & 81 & 7.8 & 438 & 42.3 & 393 & 38 & 109 & 10.5 & 1035 \\
\hline 6 & 10 & 1.0 & 80 & 7.7 & 468 & 45.2 & 393 & 38 & 84 & 8.1 & 1035 \\
\hline 7 & 7 & 0.7 & 74 & 7.1 & 470 & 45.4 & 407 & 39.3 & 77 & 7.4 & 1035 \\
\hline 8 & 3 & 0.3 & 61 & 5.9 & 491 & 47.4 & 387 & 37.4 & 93 & 9.0 & 1035 \\
\hline 9 & 64 & 6.2 & 91 & 8.8 & 402 & 38.8 & 387 & 37.4 & 91 & 8.8 & 1035 \\
\hline 10 & 11 & 1.1 & 65 & 6.3 & 511 & 49.4 & 374 & 36.1 & 74 & 7.1 & 1035 \\
\hline
\end{tabular}

$\mathrm{F}=$ Frequency

$\mathrm{P}=$ Percent

For some skills, larger proportion of the participants reported vey high or high NPD. With reference to Table 2, the highest proportion of teachers (54.6\%) indicated very high or high NPD for the first skill, maintaining language skills. The second highly demanded skill by $50.9 \%$ of population was assessing students and the third required skill indicated by $49.2 \%$ was using collaborative learning. Interestingly, teaching students with special needs was reported by about $8.8 \%$ as a skill with low appeal for PD; whereas, in the survey conducted by Kohl (2005), this instructional skill ranked the first place by foreign and second language teachers in North Carolina indicating very high or high levels of NPD.

\section{TEACHING EXPERIENCE AND NPD}

Having collected the data indicating the English Language teachers' personal NPD and NPD for instructional skills, elaborating the relationship between the participants' demographic variables and personal NPD was the final purpose of the study. To conduct the investigation, chi-square test of independence was employed. Teaching Experience, Teaching School Level, and Educational Level were the variables to be tested.

To investigate the relationship between the teachers' teaching experience and NPD, the two variables were cross tabulated. Teaching experience, with reference to the number of teaching years, was categorized into three groups. The first experience group included the teachers having 5 or less years of experience; the second group consisted those with 6 to 15 years of teaching experience, and the third group comprised the ones with more than 16 year of teaching experience.

As illustrated in Table 3, about $44 \%$ of the teachers with less than 5 years of teaching experience indicated high and very high level of NPD whereas $58.7 \%$ of the teachers with 6-15 indicated high and very high level of NPD. The English language teachers with more than 16 years of teaching experience showed the least proportion in high and very high level of the NPD. Majority of the most and the least experienced teachers indicated moderate level of NPD. Interestingly, it can be seen that the group of teachers with 6-15 years of teaching experience indicates more need for PD than the other two groups. Less than 6\% in all of the groups indicated no and/or low level of NPD. 
Table 3

Chi-square test of independence for NPD by teaching experience

\begin{tabular}{|c|c|c|c|c|c|c|}
\hline \multirow{2}{*}{$\begin{array}{c}\text { Teaching } \\
\text { Experience }\end{array}$} & \multicolumn{5}{|c|}{ NPD } & \multirow[b]{2}{*}{ Total } \\
\hline & Very High & High & Moderate & Low & No & \\
\hline \multirow[t]{2}{*}{$<5$} & $17^{\mathrm{a}}$ & 68 & 98 & 8 & 1 & 192 \\
\hline & $8.9^{\mathrm{b}}$ & 35.4 & 51.0 & 4.2 & 0.5 & 18.6 \\
\hline \multirow[t]{2}{*}{$6-15$} & 35 & 127 & 108 & 6 & 0 & 276 \\
\hline & 12.7 & 46.0 & 39.1 & 2.2 & 0.0 & 26.7 \\
\hline \multirow[t]{2}{*}{$>16$} & 32 & 223 & 277 & 28 & 7 & 567 \\
\hline & 5.6 & 39.3 & 48.9 & 4.9 & 1.2 & 54.8 \\
\hline \multirow[t]{2}{*}{ Total } & 84 & 418 & 483 & 42 & 8 & 1035 \\
\hline & 8.1 & 40.4 & 46.7 & 4.1 & 0.8 & 100 \\
\hline
\end{tabular}

Pearson $\chi^{2}=27.06 \quad \mathrm{DF}=8 \quad P$-value $=0.001$

Number of cells with expected count less than $5.0=20 \%$

${ }^{\mathrm{a}}=$ Count/Frequency $\quad{ }^{\mathrm{b}}=$ Row $\% /$ Within Teaching Experience $\%$

Table 3 shows the Pearson's chi-square test results through which $\chi^{2}=27.06$. The $\mathrm{p}$-value is 0.001 which is lower than the alpha level (0.05). This means that there is a significant relationship between the English language teachers' years of experience and their NPD. Although it is proved that the relationship is significant, Cramer's V (0.114) shows its magnitude is small.

In conclusion, it can be stated that the teachers with 6-15 years of teaching experience in comparison to the least and most experienced ones indicate higher levels of NPD and the PD developers can count on the significance of the difference between the levels of NPD and teaching experience. Therefore, the English teachers who have the first priority in being provided with PD opportunities are the ones with 6 to 15 years of teaching experience. The most experienced group indicates the lowest necessity of PD in comparison to the less experienced ones. This question might be raised why the teachers with five or less years of teaching experience indicate more moderate than higher levels of NPD. This might be because they do not have enough experience to know how much they need to be educated in what fields whereas the more experienced teachers can decide about their PD needs more wisely.

\section{TEACHING SCHOOL LEVEL AND THE NPD}

Teaching school level (Primary or Secondary) was tested whether it has a significant relationship with the teachers' NPD. Table 4 illustrates the frequency and percentage of the primary and/or secondary English language teachers indicating levels of their NPD as well as the results obtained from the Chi-square test of independence. According to the results presented, about $46.6 \%$ of primary school English language teachers indicate high and very high levels of NPD while these levels of NPD was indicated by $52 \%$ of the secondary school English language teachers. Merely $49.9 \%$ of primary school teachers and $40.5 \%$ of English language teachers in secondary schools stated moderate level of NPD. In comparison, the proportion of the teachers indicating high and very high levels of NPD in secondary schools is higher than the proportion of primary teachers indicating these levels of NPD. However most of the primary school English language teachers indicated moderate level of NPD. This implies that secondary school English language teachers proportionately need more PD activities and opportunities to be improved.

To find if the primary or secondary school English teachers indicate significantly different levels of NPD, Pearson's Chi-square test of independence was conducted. The obtained p-value (0.0001) which is less than alpha level (0.05) shows that there is a significant relationship between the teachers' levels of NPD with the teaching school level. To discuss it another way, it can be significant to state that the levels of NPD among the English language teachers in primary and secondary schools are different. To check the magnitude of the correlation, Cramer's $V(0.17)$ which is between $0.1-0.2$ proves it to be small. 
Table 4

Chi-square test of independence for NPD by teaching school level

\begin{tabular}{|c|c|c|c|c|c|c|}
\hline \multirow{2}{*}{$\begin{array}{c}\text { Teaching } \\
\text { School Level }\end{array}$} & Very High & High & Moderate & Low & No & Total \\
\hline & $38^{\mathrm{a}}$ & 280 & 340 & 22 & 2 & 682 \\
\hline Primary & $5.5^{\mathrm{b}}$ & 41.1 & 49.9 & 3.2 & 0.3 & 65.9 \\
\hline Secondary & 46 & 138 & 143 & 20 & 6 & 353 \\
\hline & 13.0 & 39.0 & 40.5 & 5.7 & 1.7 & 34.1 \\
\hline Total & 84 & 418 & 483 & 42 & 8 & 1035 \\
\hline & 8.1 & 40.4 & 46.7 & 4.1 & 0.8 & 100 \\
\hline
\end{tabular}

Pearson $\chi^{2}=29.88$

$\mathrm{DF}=4 \quad P$-value $=0.0001$

Cramer's $V=0.17$

Number of cells with expected count less than $5.0=10 \%$

${ }^{\mathrm{a}}=$ Count $/$ Frequency $\quad{ }^{\mathrm{b}}=$ Row $\% /$ Within Teaching School Level

\section{EDUCATIONAL LEVEL AND THE NPD}

The descriptive data shows there were 458 diploma, 527 bachelors, 48 masters and only $2 \mathrm{PhD}$ holders in the target population. It could be inferred that the quantity of degree and the diploma holders outnumbers the masters and PhD holders. Majority of diploma holders (50.9\%) reported moderate level of the NPD whereas the bachelors (50.3\%) and masters (57.9\%) proportionately reported higher levels of NPD. PhD holders in the target population were only two of whom one reported moderate and the other one high level of NPD. In ranking order, masters, bachelors and diplomas indicated higher levels of NPD. This illustrates that, excluding PhD holders, the higher the educational level the more the teachers report their higher NPD.

To realize if the education level of the English language teachers has significant correlation with the NPD, Chi-square test of independence was conducted twice: first, with the inclusion of all levels of NPD and education levels (Table 5), and the second time, with exclusion of ' $n o$ ' from NPD levels, and ' $P h D$ ' from education levels (Table 6). This was because the validity of Chi-square test of independence could not be approved when the number of cells with expected count less than 5.0 exceeded the threshold $20 \%$ in the first test (50\%). For the scarcity in the number of ' $P h D$ ' participants and very few numbers of ' $n o$ ' indications in levels of NPD, the second Chi-square test was conducted excluding these two cells from the cross tabulation.

To test whether or not the null hypothesis is accepted, the $p$-value must be referred to in Table 5 and Table 6. In both, it is seen to be less than the alpha level (0.05). Therefore, it can be concluded that there is a significant relationship between the education levels and the NPD levels among the English language teachers. Since the first Chi-square test was concluded not to be valid, the second test with 1025 valid cases was elaborated (Table 6).

Table 5

Chi-square test of independence for NPD by education level

\begin{tabular}{|c|c|c|c|c|c|c|}
\hline \multirow{2}{*}{$\begin{array}{c}\text { Education } \\
\text { Level }\end{array}$} & \multicolumn{5}{|c|}{\begin{tabular}{|l|l} 
& NPD \\
\end{tabular}} & \multirow[b]{2}{*}{ Total } \\
\hline & Very High & High & Moderate & Low & No & \\
\hline \multirow[t]{2}{*}{ Diploma } & $19^{\mathrm{a}}$ & 189 & 233 & 15 & 2 & 458 \\
\hline & $4.1^{b}$ & 41.3 & 50.9 & 3.3 & 0.4 & 44.3 \\
\hline \multirow[t]{2}{*}{ Bachelor } & 60 & 205 & 232 & 26 & 4 & 527 \\
\hline & 11.4 & 38.9 & 44.0 & 4.9 & 0.8 & 50.9 \\
\hline \multirow[t]{2}{*}{ Master } & 5 & 23 & 17 & 1 & 2 & 48 \\
\hline & 10.4 & 47.9 & 35.4 & 2.1 & 4.2 & 4.6 \\
\hline \multirow[t]{2}{*}{$\mathrm{PhD}$} & 0 & 1 & 1 & 0 & 0 & 2 \\
\hline & 0.0 & 50.0 & 50.0 & 0.0 & 0.0 & 0.2 \\
\hline \multirow[t]{2}{*}{ Total } & 84 & 418 & 483 & 42 & 8 & 1035 \\
\hline & 8.1 & 40.4 & 46.7 & 4.1 & 0.8 & 100 \\
\hline
\end{tabular}

Pearson $\chi^{2}=31.29 \quad \mathrm{DF}=12 \quad P$-value $=0.002 \quad$ Cramer's $V=0.10$

Number of cells with expected count less than $5.0=50 \%$

${ }^{\mathrm{a}}=$ Count/Frequency $\quad \mathrm{b}=$ Row\%/Within Education Level 
Table 6

Education level and NPD (excluding PhD, and no)

\begin{tabular}{|l|c|c|c|}
\hline & $\chi^{2}$ & DF & $P$-value \\
\hline Pearson Chi-Square & 23.12 & 6 & 0.001 \\
\hline Valid Cases & 1025 & & \\
\hline
\end{tabular}

Number of cells with expected count less than $5.0=16.7$

Cramer's $V=0.10$

The validity of the second Chi-square test is approved since the number of cells with expected count less than $5.0=16.7 \%$. Moreover, the Cramer's $V(0.01)$ in the second Chi-square test of independence indicates that the magnitude of the relationship is small. In conclusion, on the basis of the proportion of the English language teachers in the level of their NPD, it can be concluded that the masters more than the bachelors, and the bachelors more than the diplomas indicated their higher levels of NPD.

\section{CONCLUSION}

Having access to the whole population of English language teachers in Melaka, Malaysia led to survey their personal NPD and well as their NPD for instructional skills. About $99 \%$ of the participants showed their NPD in different levels. However, 48.5\% indicated their NPD in high and very high levels. In addition, instructional skills were surveyed to find how much they were needed PD for. Maintaining language skills, assessing students, and using cooperative learning were respectively the first three skills for which the teachers indicated very high or high levels of need for PD.

The participants' teaching experience, education level, and school level were tested if they have correlations with personal NPD. All were proved to have significant relationship with the NPD. This implies that the English language teachers with different years of teaching experience, educational levels, and teaching school levels have significantly different levels of NPD. In addition, it was found that all of the significant correlations' strength or magnitude is small. From practical viewpoint, it can be concluded that PD developers would design professional activities or opportunities with reference to the NPD levels of the teachers and certain demographic variables. Taking all the test results into consideration, providing PD opportunities for the teachers should be prioritized on the basis of the variable that were proved to be relevant to the levels of NPD.

\section{AUTHOR INFORMATION}

Koroush Khandehroo is the Head of English Department at IAU, Neyshabur, Iran. Dr. Khandehroo's most liked research areas are the ESL/EFL Professional Development, and Teaching Reading and Vocabulary to EFL learners. He has also conducted studies on the ESL teachers' burnout in Malaysia. kkhandehroo@yahoo.com Islamic Azad University, Neyshabur Branch, Iran

Jayakaran Mukundan is Associate Professor at the Faculty of Educational Studies, Universiti Putra Malaysia. Dr. Mukundan's main research focus areas are the Teaching of Writing, ELT Materials Development and Evaluation and ELT Professional Development. He is Director on the Board of Directors of The Extensive Reading Foundation and Visiting Fellow, Leeds Metropolitan University, UK. jaya@educ.upm.edu.my University Putra Malaysia, Serdang, Selangor, Malaysia

Zhinoos Kamal Alavi has been involved in multimedia and its use in English Language Teaching. Her main expertise is to do research on the EFL learners' content and vocabulary comprehension with the help of interactive video based teaching techniques. She has also had studies on the effectiveness of subtitled videos on vocabulary learning. jinus.alavi@yahoo.com University Multimedia, Malaysia

\section{REFERENCES}

1. Coakes, S. J., \& Lyndall, S., SPSS version 14.0 for windows: analysis without anguaish. Australia: Willey. 2007. 
2. Desimone, L. M., Improving impact studies of teachers' professional development: toward better conceptualizations and measures. Educational Researcher, 38 (3), 181-199, 2009.

3. Garet, M. S., Porter, A. C., Desimone, L., Birman, B. F., \& Yoon, K. S., What makes professional development effective? results from a national sample of teachers. American Educational Research Journal 38 (4), 915-945, 2001.

4. Gersten, R., \& Santoro, L. E., Teacher study group: impact of the professional development model on reading instruction and student outcomes in first grade classrooms . American Educational Research Journal , 47, 694-739, 2010.

5. Kohl, G. A., The professional development needs of K-12 ESL and foreign language teachers: a descriptive study. North Carolina, United States of America: University of North Carolina, 2005.

6. Lucks-Horsley, S., \& Matsumoto, C., Research on professional development for teachers of mathematics and science: the state of the scene. School Science and Mathematics, 99, 1999.

7. Mukundan, J., \& Khandehroo, K., Burnout among English language teachers in Malaysia. Contemporary issues in education research, 1 (3), 71-76, 2009.

8. Pillay H., \& Thomas M., A nation on the move: from chalkface to laptops. In J. Mukundan, D.Z. Abidi, D.S.R. Singh, ELT Matters 2: Developments in English Language Learning and Teaching. Serdang, UPM Press, 2004.

9. Villegas-Reimers, E., Teacher professional development: an international review of literature. UNESCO: International Institute for Educational Planning, 2003. 